\title{
QUANTUM MECHANICAL CALCULATIONS OF ELECTRONIC STRUCTURES OF MULTIPLE SPHALERITE CLUSTERS
}

\author{
V. I. Pokhmurskii ${ }^{1}$, V. I. Kopylets ${ }^{1}$, S. A. Kornii ${ }^{1}$, O. M. Janchuk ${ }^{2}$, G. A. Biletska ${ }^{3}$ \\ ${ }^{1}$ Karpenko Physico-Mechanical Institute of the National Academy of Sciences of Ukraine \\ 5 Naukova Str., Lviv, UA-79601, Ukraine \\ ${ }^{2}$ Volyn State University, 13 Volia Pr., Lutsk, 43025, Ukraine \\ ${ }^{3}$ Technological University "Podillia", 5 Instytuts'ka Str., Khmelnytskyi, UA-29000, Ukraine
} (Received March 1, 2000)

\begin{abstract}
Atomic charges and energy levels of ZnS, ZnSe, CdS and CdSe multiple clusters were calculated by the Extended Huckel method for real structures of the semi-conductors. The variation of their electronic properties has been depicted in the dependence of single cluster separations. CdSe is more sensitive to such separations than ZnS and CdS. Orbital energy levels showed a significant dependence on cluster coupling at a distance comparable with the individual cluster size. Charge distributions in far regions did not give any variations with the intercluster distance alteration in contrast to little disturbatioins of charges in face-to-face coupled atoms, especially in chalcogenes.

Key words: clusters, atomic charges, energy levels, quantum mechanical calculations.
\end{abstract}

PACS number(s): 31.25.Qm, 36.40.-c

\section{INTRODUCTION}

Regular structure groups of atoms, separated theoretically or experimentally and known as clusters are of comparable interest as they regard a strong dependence of their properties on the atomic scale dimensions inside and outside. In real systems, clusters are located at solid substrates or matrices. If intercluster distances are of several nanometers, the clusters can be considered as independent. Their properties are derived from simple calculations of relatively small individuals, constructed by dogens or even hundreds of atoms. In the case of closely packed systems cluster interactions become significantly overlapping by their molecular orbitals, and the whole complex acts as a separate unit. Of cause, the degree of the interaction is determinated by the distance value between the clusters. So it would be important to study quantitatively their electronic structure variations due to intercluster distances.

The results of theoretical studies of multiple nanometer size clusters in the approximation of effective masses showed an essential effect of such distances in the appearance of level crossing phenomena, oscillator strength alterations, excitation modes, etc. Unfortunately, the effective mass approximation does not allow to take into account the physical nature of bonds in semiconductor clusters. Thus, to show the intercluster dependence one may use their molecular simulation in appropriate quantum mechanical methods. The problem would become simpli- fied and often in the only way solvable if empirical atomic parameters and experimental cluster (or monocrystall) geometry determine electronic properties. In this aspect molecular orbital theory can play a useful role describing such a large complex as coupled clusters of a semiconductor. The only restrictions are computational possibilities of the machines used. Regarding modern PC one is able to calculate electronic structures for clusters built of several hundreds of atoms with non-transition metals included.

Up to date most of the properties of semiconductor and metal clusters were obtained theoretically for isolated units, accounting environment particles in some cases $[1,2]$. First principle calculations are impossible for large clusters on PC in molecular orbital approximation if symmetry conditions of the clusters are destroyed under their mutual perturbations. So semiempirical methods such as Extended Huckel Theory (EHT) as giving realistic results in short times may be successfully applied to solve the problem.

\section{THEORY AND CALCULATION PROCEDURE}

The dramatic moment of EHT correct application is the appropriate choice of the Helmholz constant $K$ in Hamiltonian off-diagonal matrix elements. The $K$ value was taken as 1.82 to fit the thermodynamics of diatomic molecules $M e-X \quad(M e=\mathrm{Zn}, \mathrm{Cd}, X=\mathrm{S}, \mathrm{Se})$. Atomic parameters were also modified (Table 1 ).

\begin{tabular}{|c|c|c|c|c|c|c|c|c|c|}
\hline \multirow{2}{*}{ Atom } & \multicolumn{6}{|c|}{ Orbital exponents } & \multicolumn{5}{|c|}{ Hamiltonial diagonal matrix elements in $\mathrm{eV}$} \\
\cline { 2 - 10 } & $s$ & $p$ & $d$ & $s$ & $p$ & $d$ & $d$ & $d$ & $d$ \\
\hline $\mathrm{S}$ & 1.825 & 1.825 & 1.600 & -22.000 & -13.000 & -8.500 & 0.000 & 1.000 & 0.000 \\
\hline $\mathrm{Zn}$ & 1.730 & 1.034 & 7.428 & -8.500 & -4.500 & -22.500 & 0.000 & 0.650 & 3.150 \\
\hline $\mathrm{Se}$ & 2.420 & 2.360 & 0.000 & -20.800 & -14.500 & 0.000 & 0.000 & 0.000 & 0.000 \\
\hline $\mathrm{Cd}$ & 1.800 & 1.450 & 3.785 & -8.990 & -4.650 & -13.200 & 0.000 & 1.000 & 0.000 \\
\hline
\end{tabular}

Table 1. Modified atomic parameters for EHT. 
Multiple clusters were simulated by only two coupled clusters distant from each other by $r, 2 r$, and $3 r \AA$, were $r$ is the dimension of the single cluster considered. A relatively rough approximation such as ETH is expected to give quite appropriate results because of its ability to represent band structure distribution correctly [3].

All calculations were carried out by the Extended Huckel method (EHM) of the HYPERCHEM (release 5.1) program on PC Intel Pentium-166 with $32 \mathrm{MB}$ of fast memory.

\section{RESULTS AND DISCUSSION}

Sphalerite structure of coupled clusters of CdS is shown in Fig. 1. The rest of the other compounds are of the same structure with appropriate geometries taken from experimental data.

A quasicontinuous energy spectrum was obtained for all single clusters of the following composition $M e_{13} X_{32}$ ( $M e=\mathrm{Zn}, \mathrm{Cd} ; \mathrm{X}=\mathrm{S}, \mathrm{Se}$ ). The growth of cluster size leads to some improvement of band distribution, but the costs of it are too high: the computational time increases dramatically even for the formations with a hundred of atoms. In the process of coupling the initial clusters en- ergy levels undergo most significant shifts for distances in $r \AA$ and for CdSe, while $\mathrm{ZnS}$ is just a little active. The energy level disturbation is less noticeable for greater intercluster distances: $2 r$ and $3 r$, especially.
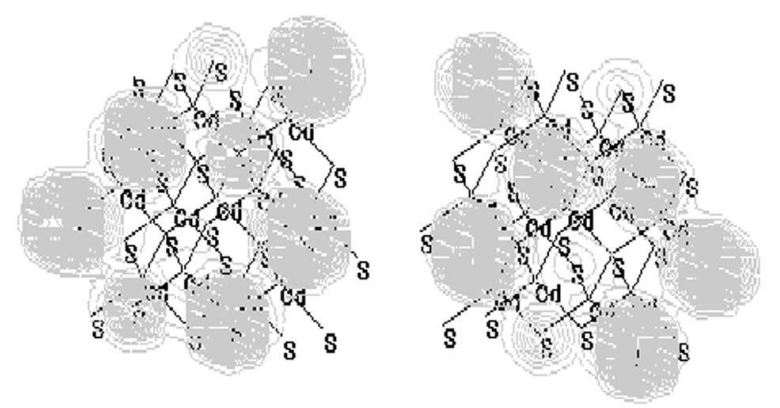

Рис. 1. Coupled cluster $\mathrm{Cd}_{13} \mathrm{~S}_{32}$. With contour map of charge density in the central cut plane.

Coupled clusters were found to loose their stability as compare of with its total energy with the sum of separated units. The stability of coupled clusters grows in the following consequence: $\mathrm{ZnS}$, ZnSe, CdS, CdSe as may be seen from Table 2.

\begin{tabular}{|c|c|c|c|}
\hline Clusters & Distance & Total energy change, $\mathrm{eV}$ & HOMO-LUMO difference, $\mathrm{eV}$ \\
\hline \multirow{3}{*}{$\mathrm{ZnS}$} & 1 & -0.1256 & 3.6512 \\
\cline { 2 - 4 } & 2 & -0.0145 & 5.5227 \\
\cline { 2 - 4 } & 3 & -0.0122 & 6.0125 \\
\hline \multirow{3}{*}{$\mathrm{ZnSe}$} & 1 & -0.1677 & 3.1723 \\
\cline { 2 - 4 } & 2 & -0.0196 & 4.0615 \\
\cline { 2 - 4 } & 3 & -0.0184 & 4.2673 \\
\hline \multirow{3}{*}{$\mathrm{CdS}$} & 1 & -0.1849 & 2.6299 \\
\cline { 2 - 4 } & 2 & -0.0261 & 3.2576 \\
\cline { 2 - 4 } CdSe & 3 & -0.0240 & 3.4024 \\
\cline { 2 - 4 } & 1 & -0.4577 & 2.2830 \\
\cline { 2 - 4 } & 2 & -0.0385 & 2.6475 \\
\hline
\end{tabular}

Table 2. EHM characteristics of clusters (intercluster distance are in units of a single cluster size).

For large intercluster distances the alteration of total energies are negligible and the cluster coupling could occur. The levels formed by more localized $d$-orbitals of uncoupled clusters do not undergo any sufficient alterations as compared with those of single ones. During the coupling some changes of the level bands were fixed near the 'extraordinal' levels: highest occupied molecular orbitals (HOMO) and lowest unoccupied molecular orbitals (LUMO). In the first case it can contribute to first optical transitions and to the appearance of additional states in the region of unoccupied states. This allows for a somewhat careful assumption concerning the increased sensitivity of the excited states with respect to cluster coupling.

Charge redistribution due to cluster coupling was found to be just slightly sensitive to distances. For $2 r \AA$ the values vary only for face to face located chalcogene atoms (Table $3 \mathrm{a}, \mathrm{b}$ ).

Such a weak influence of the charge disturbation corresponds to "high" stability of electronic density for such complex clusters. For distances in $r \AA$ the atomic charges of zink and cadmium atoms were calculated as both decreased and increased (considerably for Cd), particularly for the metals in the sites opposite to chalcogene atoms of the partner cluster. All chalcogenide atoms are less contributive to charge redistribution. 


\begin{tabular}{|l|c|c|c|c|c|c|}
\hline & \multicolumn{7}{|c|}{ Charges on atom, $e$} \\
\cline { 2 - 7 } Distance $L, \mathrm{Zn}(1)$ & $\mathrm{Zn}(2)$ & $\mathrm{Zn}(3)$ & $\mathrm{Cd}(1)$ & $\mathrm{Cd}(2)$ & $\mathrm{Cd}(3)$ \\
\hline \hline$L=r$ & 0.125 & 0.267 & 0.415 & & & \\
\hline$L=2 r$ & 0.127 & 0.267 & 0.415 & & & \\
\hline$L=3 r$ & 0.127 & 0.267 & 0.415 & & & \\
\hline$L=r$ & 0.116 & 0.243 & 0.415 & & & \\
\hline$L=2 r$ & 0.118 & 0.244 & 0.415 & & & \\
\hline$L=3 r$ & 0.118 & 0.244 & 0.415 & & & \\
\hline$L=r$ & & & & 0.129 & 0.261 & 0.478 \\
\hline$L=2 r$ & & & & 0.132 & 0.262 & 0.478 \\
\hline$L=3 r$ & & & & 0.131 & 0.262 & 0.478 \\
\hline$L=r$ & & & & 0.104 & 0.213 & 0.365 \\
\hline$L=2 r$ & & & & 0.109 & 0.215 & 0.366 \\
\hline$L=3 r$ & & & & 0.110 & 0.215 & 0.366 \\
\hline
\end{tabular}

Table 3a. Charges on atoms of the clusters calculated by EHM.

\begin{tabular}{|l|r|r|r|r|r|r|}
\hline \multirow{2}{*}{ Distance $L, \AA$} & \multicolumn{7}{|c|}{ Charges on atom, $e$} \\
\cline { 2 - 7 } & $\mathrm{S}(1)$ & $\mathrm{S}(2)$ & $\mathrm{S}(3)$ & $\mathrm{Se}(1)$ & $\mathrm{Se}(2)$ & $\mathrm{Se}(3)$ \\
\hline \hline$L=r$ & -0.461 & 0.267 & 0.415 & & & \\
\hline$L=2 r$ & -0.463 & 0.267 & 0.415 & & & \\
\hline$L=3 r$ & -0.463 & 0.267 & 0.415 & & & \\
\hline$L=r$ & & & & -0.440 & -1.202 & -1.444 \\
\hline$L=2 r$ & & & & -0.441 & -1.203 & -1.444 \\
\hline$L=3 r$ & & & & -0.440 & -1.203 & -1.444 \\
\hline$L=r$ & -0.454 & -1.536 & -1.601 & & & \\
\hline$L=2 r$ & -0.458 & -1.537 & -1.601 & & & \\
\hline$L=3 r$ & -0.458 & -1.537 & -1.601 & & & \\
\hline$L=r$ & & & & -0.454 & -1.536 & -1.601 \\
\hline$L=2 r$ & & & & -0.461 & -1.542 & -1.604 \\
\hline$L=3 r$ & & & & -0.462 & -1.543 & -1.604 \\
\hline
\end{tabular}

Table 3b. Charges on atoms of the clusters calculated by EHM.

Energy gaps may be immediately calculated from the obtained band spectra as differences of HOMO and LUMO levels (Table 2) and compared with experimental optical spectra. These values are more sensitive to intercluster separations, especially in the case of CdSe than atom charges. Therefore they are more appropriate to experimental verification of the cluster coupling effects. Energy gaps (in the best way for CdS and CdSe) were significantly influenced during an intercluster increase.

The theoretical study of semi-conductor electronic structure alteration resulting from a close interaction of small clusters showed that any significant effect might be noticed only for very close distances. Nevertheless changes of the properties studied are very small even for distances in two cross-cluster sizes as compared with that of individual clusters. Of course, this fact is not an unexpected one since strong interaction occurs only at short distances. Because of very approximative character of EHT no one can claim that only from double intercluster separation weak interaction takes place, but must argue that there is accelerated decrease of physical properties with interparticle separations. The small clusters considered here have a molecular-like nature and their boundaries are very sensitive to environment which is expressed in higher polarizability (than in the bulk), ununiform electronic density distribution, etc. However, the main basis of the weak intercluster interaction is the nature of the chemical bonds in semiconductors themselves contrary to the nature of those in, e.g. metals, when explicit interaction was observed at distances in dozens of single cluster sizes [4]. Though metal behaviors differ from those of semi-conductors and their calculation is based on continuity models, the mentioned contradiction does not support inefficiency of the semiempirical methods, including EHM.

Present calculations may be compared with the results of a study of multiple quantum box models [5] and quantum well systems constructed of semiconductors [6]. Here energy level shifts occur for small distances between single boxes or wells. A collective character of the semiconductor electronic structure was assumed when calculations were made in the effective mass approximation.

Thus, the calculation by EHM showed the effect of relatively strong intercluster interaction in the case of their units distant each from other by the single cluster cross-size. For double and triple distances the cou- 
pling effect is found to be small. Charge distribution slightly alters (0.001-0.01) and energy levels shift considerably (0.01-0.1 eV) while energy gaps are narrowed by significant values $(1-4 \mathrm{eV})$. The latter effect can occur in optical adsorption spectra. Band distribution has a more semiconductor-like character in a coupled clusters as compared with single ones. The maximum changes of the all above said behaviors are observed for CdSe, the minimums are depicted for $\mathrm{ZnS}$.

[1] M. A. All-Laham, K. Raghavachami, J. Chem. Phys. 98, $8770(1991)$.

[2] A. Hagfeldt, R. Bergstrom, H. O. G. Siegbahn, S. Luhell, J. Phys. Chem. 97, 12725 (1993).

[3] P. Alemany, R. S. Boorse, J. M. Burlitch, R. Hoffman, J. Chem. Phys. 97, 8464 (1993).

[4] C. H. Dasso, A. Vitturi, Phys. Rev. B 44, 2699 (1993).

[5] T. Demel, D. Heitmann, P. Grambow, K. Ploog, Phys. Rev. Lett. 64, 788 (1990).

[6] C. Yuang, R. Y. Hwang, H. C. Pan, C. Chang, B. J. Lee, J. Appl. Phys. 70, 4973 (1991).

\title{
КВАНТОВОМЕХАНІЧНI РОЗРАХУНКИ ЕЛЕКТРОННИХ СТРУКТУР ЗГРУПОВАНИХ СФАЛЕРИТНИХ КЛАСТЕРІВ
}

\author{
В. І. Похмурський ${ }^{1}$, В. І. Копилещь ${ }^{1}$, С. А. Корній ${ }^{1}$, О. М. Янчук ${ }^{2}$, Г. А. Білецька ${ }^{3}$ \\ ${ }^{1}$ Фізико-механічний інститут ім. Карпенка Національной академій наук Украйни, \\ вул. Наукова, 5, Львік, 79601, Украӥна \\ ${ }^{2}$ Волинсъкий держсабний університет, пр. Волі, 13, Луиък, 43025, Украйна \\ ${ }^{3}$ Технологічний університет "Поділлл", \\ вул. Інститутсъка, 5, Хмельнищький, 29000, Украӥна
}

\begin{abstract}
Розширеним методом Гюккеля розраховано атомні заряди та енергетичні рівні згрупованих кластерів $\mathrm{Zn}, \mathrm{ZnSe}$, CdS та CdSe для реальних структур цих напівпровідників. Зміну їніх електронних властивостей було проаналізовано залежно від відстаней між одиночними кластерами. CdSe $\epsilon$ чутливішим до розділення, ніж ZnS i CdS. Рівність орбітальних енері ій показала іх значну залежність від ефекту здвоєння кластерів при віддалях, сумірних із розмірами окремих кластерів. Розподіл заряду в дальніх ділянках не змінюється при віддаленні кластерів, на відміну від невеликого збурення зарядів на атомах, розташованих один навпроти іншого, особливо для халькоґенідів.
\end{abstract}

